\title{
Habitability on Mars from a Microbial Point of View
}

\author{
Frances Westall, Damien Loizeau, ${ }^{2,3}$ Frédéric Foucher, Nicolas Bost, ${ }^{1,4}$ \\ Marylène Betrand, Jorge Vago, ${ }^{2}$ and Gerhard Kminek ${ }^{2}$
}

\begin{abstract}
Extraterrestrial habitability is a complex notion. We briefly review what is known about the origin of life on Earth, that is, life based on carbon chemistry and water. We then discuss habitable conditions (past and present) for established life and for the survival of microorganisms. Based on these elements, we propose to use the term habitable only for conditions necessary for the origin of life, the proliferation of life, and the survival of life. Not covered by this term would be conditions necessary for prebiotic chemistry and conditions that would allow the recognition of extinct or hibernating life. Finally, we apply this concept to the potential emergence of life on Mars where suitable conditions for life to start, proliferate, and survive have been heterogeneous throughout its history. These considerations have a profound impact on the nature and distribution of eventual traces of martian life, or any precursor, and must therefore inform our search-for-life strategies. Key Words: MarsMicrobial life-Punctuated habitability. Astrobiology 13, 887-897.
\end{abstract}

\section{Introduction}

O UR UNDERSTANDING of the potential of other planets and satellites in our Solar System to host microbial life has increased considerably in the last decade. The icy satellites of the outer planets no longer appear completely inhospitable, especially when viewed as warmer and more active bodies during their early history. Hypotheses concerning the possibility of life on Mars wax and wane as new data and new models related to its aqueous history appear. We tend to automatically equate the availability of water with the guarantee of conditions conducive to life. However, from a microbial point of view, the situation is very different depending on whether we are dealing with the emergence of life, with established or flourishing life, or with life in a survival or dormant mode. The term habitable is misleading when applied to conditions in which prebiotic chemistry can lead to the origin of life. The principal requirement of a prebiotic environment would be the simultaneous coexistence of the ingredients of life and the range of chemical and physicochemical reactions necessary to result in a protolife entity-a chemical reactor of sorts. It is entirely possible that an environment conducive to prebiotic chemical processes leading to the origin of life could have been spatially confined and toxic compared to the present terrestrial environment yet able to provide that first spark, with subsequent evolution occurring eventually in other locations. Similarly, conditions that would allow life to flourish are likely to be different from those in which the molecular building blocks formed. Thus, in this contribution we introduce a concept for the use of the term habitable and apply this to life on Mars.

We start with a review of the general understanding concerning the origin of life on Earth. We then consider the ability of life to establish itself opportunistically in any habitable environment, as well as its faculty for survival. Finally, we extend this analysis to Mars from the point of view of the origin and survival of microbial life, recognizing that conditions for both the origin of life and for habitability on the planet would have been heterogeneous.

\section{Habitability and Life}

\subsection{The building blocks: availability of prebiotic molecules and water}

Life as we know it is based on carbon macromolecules and water. Carbon, oxygen, nitrogen, and hydrogen are among the five most common elements in the Solar System and are essential for all organisms on Earth. Chemical reactions are ubiquitous, and one or more of these elements is a constituent in most molecules found in the Universe. However, the universality of chemistry does not necessarily mean the universality of life, because the criteria for the emergence of life (at least the

${ }^{1}$ CNRS-OSUC-Centre de Biophysique Moléculaire, Orléans, France

${ }^{2}$ ESA-ESTEC, Noordwijk, the Netherlands.

${ }^{3}$ Laboratoire de Géologie de Lyon, Terre, Planètes, Environnement, Villeurbanne, France.

${ }^{4}$ CNRS-OSUC-Institut des Sciences de la Terre d'Orléans-BRGM, Orléans, France. 
carbon- and water-based life that we know) are quite particular. In this respect, environmental conditions have a strong influence on the kinds of molecules that can be formed (Brack, 1999).

In the interstellar medium, more than 150 organic molecules have been detected in dense clouds. Among these, 50 are relatively complex, having more than six carbon atoms. These molecules can be formed in the icy mantles of tiny interstellar grains (Herbst and van Dishoeck, 2009; de Marcellus et al., 2011). Important prebiotic molecules (organic molecules formed without the intervention of life, i.e., abiotically) have been detected, such as formic acid $(\mathrm{HCOOH})$, hydrogen cyanide $(\mathrm{HCN})$, and formaldehyde (HCHO) (Oró, 1961; Chyba et al., 1990; Maurette, 1998; Bernstein et al., 1999; Sephton and Botta, 2008), that are incorporated into the carbonaceous matter of interstellar ices and dust particles, comets, meteorites, and micrometeorites. Such materials would have rained down on the early planets in huge quantities, contributing to the inventory of organics and volatiles, including water (Chyba and Sagan, 1992).

On Earth, the prebiotic organic ingredients for life had both endogenic and exogenic sources. Endogenic sources included the primordial, slightly reducing atmosphere and active hydrothermal systems. Organic compounds (such as sugars, amino acids, and nucleobases) may have formed in Earth's early atmosphere via the Strecker reaction of ammonia, formaldehyde, and hydrogen cyanide (Miller, 1953; Johnson et al., 2008). The above reactants may have been produced through photochemistry and/or lightning discharges in a reducing atmosphere. Indeed, Pascal (2013) and Pross and Pascal (2013) noted that only photochemistry and/ or the momentary high temperatures produced during electrical discharges in the atmosphere (or by impact shock) can create the necessary energy kinetics to jump-start the process of chemical evolution (or drive to greater "dynamic kinetic stability") leading to abiogenesis and the appearance of simple life. Other compounds, such as hydrocarbons and fatty acids, could have been synthesized in the oceanic crust through hydrothermal Fischer-Tropsch reactions (Baross and Hoffman, 1985; Bougault et al., 1993; Russell et al., 2010). Exogenic sources included comets, meteorites, and micrometeorites. Amino acids in carbonaceous meteorites were probably synthesized by subsequent aqueous alteration of the parent body, also via the Strecker pathway (Bada et al., 1994). Other plausible mechanisms for providing the key molecules necessary for the Strecker reaction are bolide impact shock synthesis in a slightly reducing atmosphere and the pyrolysis of existing bolide organics (Bada et al., 1994). Chyba and Sagan (1992) estimated the flux of carbon during the period of heavy bombardment, about 4 billion years ago, at about $10^{8} \mathrm{~kg}$ /year. With regard to the present, Maurette et al. (2001) calculated a flux of 20,000 tons/year of micrometeorites accreting on Earth. Impressive as this may sound, however, when spread over a primordial global ocean, the abundance of delivered organics in the waters must have been the equivalent of "a very dilute primordial soup."

\subsection{The first spark: origin of life}

In the previous section, we briefly addressed the reducing chemical environments required for the formation of prebiotic organics. However, the conditions necessary for their subsequent association into more complex molecules, even- tually leading to functional life-forms (i.e., the process of abiogenesis, Pross and Pascal, 2013), were likely to have been more restrictive (Ourisson and Nakatani, 1999; Pascal et al., 2006; Pollack et al., 2009). Thermodynamically, molecular agitation is necessary to induce macromolecules to adhere to each other, but too much agitation will lead to their disintegration. An effective concentration process is fundamental for this type of chemistry. For example, free-floating organic (macro)molecules could have accumulated by attachment to other molecules passively fixed to the surfaces of reactive minerals, such as pyrite (e.g., Huber and Wächtershäuser, 1998). For these sorts of reactions to take place, organics must be present in large quantities in physicochemical conditions compatible with liquid water and in an environment in which the kinetics of macromolecule formation is higher than that of their degradation-a sort of natural chemical reactor where the required ingredients can flow in, concentrate, react, and where the resulting products can be transported out to undergo further physicochemical evolution. Possible reactors may have included settings combining a regular flow of organic-laden waters possibly including a mild thermal gradient and either mineral grains or a porous medium capable of mediating reactions. Note that macromolecular selforganization can occur at water temperatures below $80^{\circ} \mathrm{C}$, but at higher temperatures the molecules risk disaggregation (Larralde et al., 1995). Relatively stable conditions would have been necessary for the assemblage of these molecules into primitive life entities. However, the simple accumulation and organization of macromolecules is not sufficient to form a living cell. Three essential functions must be ensured by the molecules and must coexist for life to arise: confinement, metabolism, and transmission of information.

There are presently two preferred hypotheses regarding the environment in which macromolecules on Earth could have aggregated under sufficiently stable conditions to form a primitive cell: hydrothermal vents and the littoral environment with its tidal swash (Figs. 1 and 2). Yet another environment has been suggested by Benner et al. (2010), who proposed streams on dry land containing exposed serpentinite crust, the streams being characterized by changing $\mathrm{pH}$ conditions, as ideal environments for the formation of one of the key macromolecular components of life, ribose. Given that early Earth was more likely to have resembled an ocean planet than a dry one, this scenario seems less reasonable.

Modern hydrothermal vent systems tend to be episodic, appearing and disappearing relatively quickly. On young Earth, however, hydrothermal activity must have been much more prevalent than today, with hydrothermal systems probably being far larger and more extensive. Although fluid temperatures within modern hydrothermal vents may be far too high for the formation of macromolecules, the temperature gradient immediately adjacent to the vents can be very strong. Today, temperatures range from $>350^{\circ} \mathrm{C}$ at black smoker vent exits to $<2^{\circ} \mathrm{C}$ a little more than $50-100 \mathrm{~cm}$ away. On early Earth, silicon and oxygen isotope data suggest that global ocean temperatures were higher than at present, at least in the vicinity of the crustal surface, because of the higher heat flux from the mantle (about three times higher, Sleep, 2010) that drove extensive volcanism and also because of the pervasive hydrothermal circulation in the upper crust (cf. Buffett, 2003; Hofmann and Bolhar, 2007; van den Boorn et al., 2007). Even with ocean temperatures 
FIG. 1. Possible origin of life in porous (beehive), hydrothermal vents. (a) Sketch showing a porous beehive structure where hydrothermal fluids and seawater can circulate, leading to the accumulation of organic molecules. The reduced mineral surfaces within the vent pores could be favorable locations for the structural organization of macromolecules. We hypothesize the formation of lipid micelles in these environments and the incorporation of information-transferring molecules within the micelles, perhaps due to moderate agitation of the hydrothermal effluent. (b) Image of a modern black smoker (image credit: National Oceanographic and Atmospheric Administration). Color images available online at www.liebertonline.com/ast

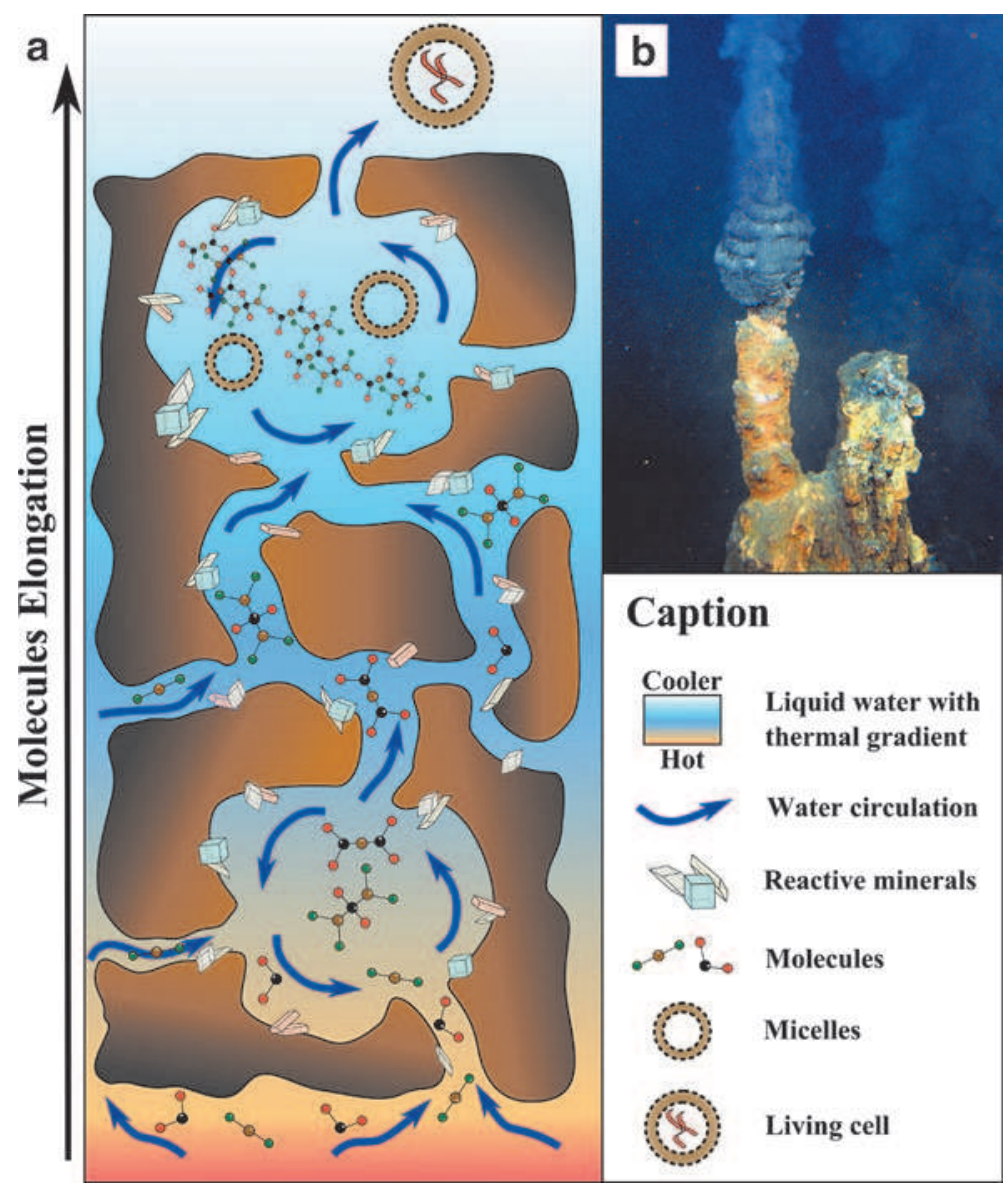

ranging from $<50^{\circ} \mathrm{C}$ to $\sim 70^{\circ} \mathrm{C}$, the temperature gradient near vent structures would still have been steep.

Hydrothermal deposits and rocks in the immediate vicinity of vents contain minerals with very reactive surfaces, such as pyrite and sphalerite, that may have been implicated in the processes leading to the appearance of life (Huber and Wächtershäuser, 1998; Hazen and Sverjensky, 2010). At the very least, redox reactions at their surfaces could have provided the energy needed for primitive life. Hydrothermal edifices formed by the precipitation of vent fluid minerals can be extremely porous (Fig. 1), a characteristic that makes them potential locations in which macromolecules can be concentrated and, thus, give rise to the first cells (Alpermann et al., 2010; Russell et al., 2010). It is noteworthy that recent experiments have shown the ability of primitive cells to retain RNA and DNA oligonucleotides at temperatures up to $100^{\circ} \mathrm{C}$ (Mansy and Szostak, 2008).

The other scenario for the origin of life on Earth is in the littoral environment (Fig. 2). The possibility of subjecting macromolecules to wetting/drying cycles in the dynamically active environment of a tidal beach could stimulate the association of different macromolecular components. In principle, a sloping beach can act as a natural "chromatographic column" on which simple organics can be deposited and "eluted" through sand grains by the receding waves, over and over again, leading to chemical enrichment (Bada, 2004). For example, Deamer et al. (2002) were able to induce the incorporation of RNA into lipid vesicles in an experiment simulating these conditions.
The length of time necessary for macromolecules to selforganize and form primitive cells is not known, but it is believed to be relatively short, of the order of hundreds of thousands to perhaps a few million years (Orgel, 1998). The kinetics of the actual process(es) necessarily had to be rapid, otherwise the macromolecular components of the first cells would have been broken down when exposed to early Earth's hostile conditions. Once life appeared, colonization of the connected environment would have been rapid, on the scale of years to thousands of years (Sleep, 2010).

Summarizing, for the origin of life, moderately dynamic aqueous conditions, for example in a hydrothermal or a littoral environmental setting influenced by waves, are conditions that facilitate the initial aggregation of available prebiotic molecules into macromolecules. Thereafter, calmer environments would have been necessary for the final assemblage of the macromolecules into very simple, selfreproducing and evolving cells. This is assumed to have taken place on a timescale of $10^{5}$ to some $10^{6}$ years.

\subsection{Sustaining conditions: established life}

Once established, simple cells would have been able to rapidly take advantage of any habitable conditions, even ephemeral ones. Microbial cells are the archetypal opportunists. Microbes are adaptable because they have the ability to switch from one energy transfer pathway to another, depending upon their availability. Provided the necessary ingredients and the physicochemical conditions for liquid 


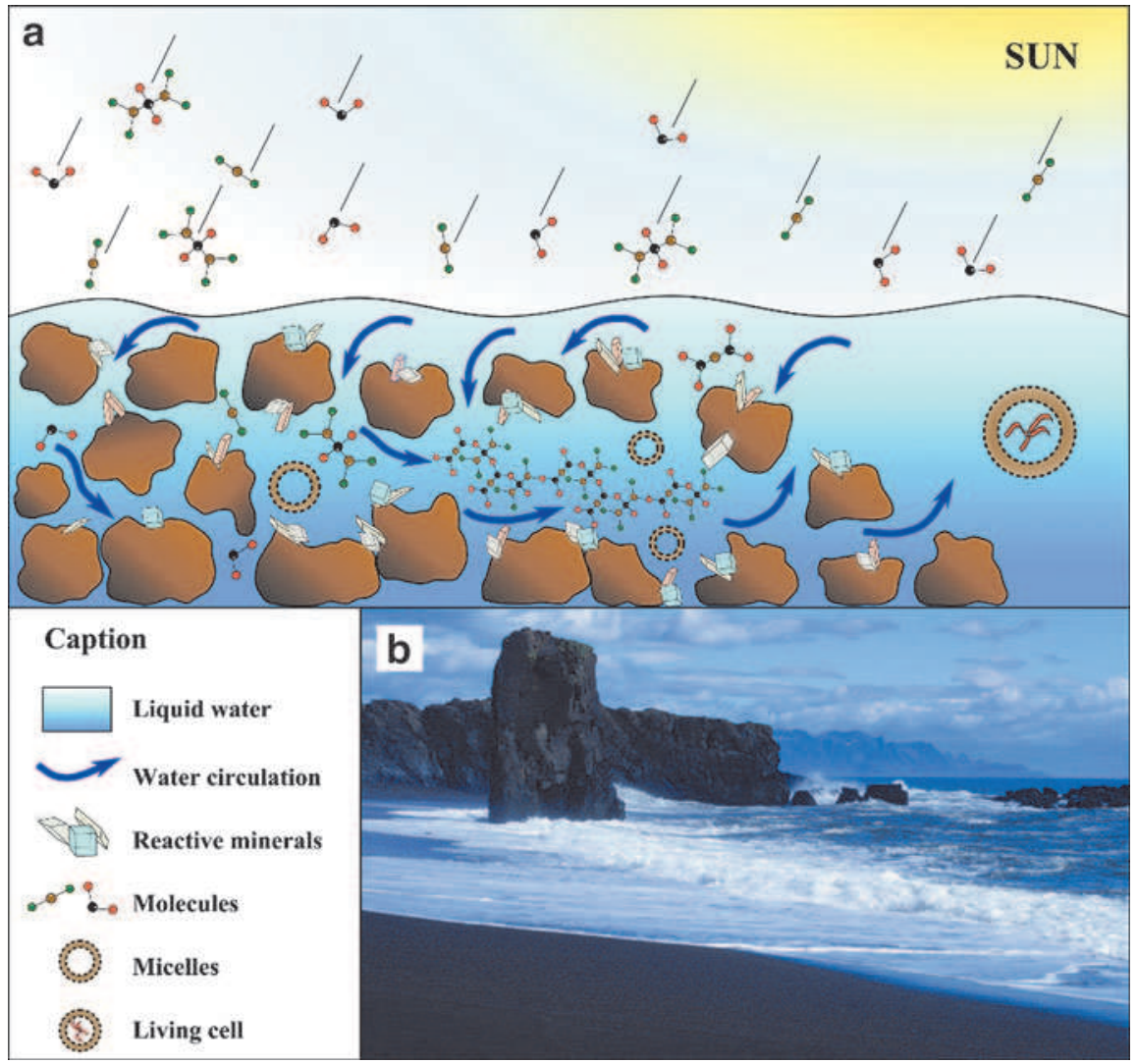

FIG. 2. Possible origin of life in the swash zone. (a) Sketch showing the possible role of the reactive surfaces of volcanic detrital deposits for the structural organization of macromolecules within the swash zone. Wetting and drying cycles have been shown to be effective for the incorporation of information-transferring molecules into lipid micelles (e.g., Deamer et al., 2002). (b) Photo of the modern swash zone on a volcanic beach, Iceland (image credit: Philippe Lefebvre). Color images available online at www.liebertonline.com/ast

water are present, simple living cells can rapidly "invade" any newly available habitat. The spatial scales associated with this kind of colonization are the spatial scales of the cells themselves. Anaerobic microbes form colonies that can vary in size depending on the availability of carbon, nutrients, and energy. They may form small colonies of the order of tens of microns on the surfaces of particles (e.g., Westall and Southam, 2006; Westall et al., 2011), or they can form vast mats, for example in the vicinity of hydrothermal vents (Sievert and Vetriani, 2012) (N.B. these mats form at the interface with oxygenated and sulfate-rich seawater; seawater on early Earth was sulfate poor because of the lack of oxygen; Grotzinger and Kasting, 1993). Microbes will live in an environment for as long as favorable conditions persist.

Given the volcanic and hydrothermal environments available on early Earth, the most likely sources of energy for the earliest life-forms would have been $\mathrm{H}_{2}$ from the hydrolysis of water or serpentinization and oxidants $\left(\mathrm{O}_{2}, \mathrm{NO}_{3}{ }^{-}\right.$, or $\mathrm{SO}_{4}{ }^{2-}$ ) from subsurface brines. These electron donors would have fueled chemoautotrophic life-forms (Sleep and Bird, 2007; Gaucher et al., 2010) that used metabolisms such as methanogenesis or sulfite reduction. The first life-forms could have rapidly colonized the terrestrial oceanic environment, including the seafloor, and subsurface habitats, such as fractures, pores, deep sediments, and groundwater aquifers.

Earth's subsurface is today, and was probably in the past, an important habitat for life. Indeed, Sleep (2010) suggested that subsurface refuges for life during/after sterilizing asteroid impacts were $\sim 1 \mathrm{~km}$ deep. Abyssal ocean sediments host $5-15 \%$ of the total terrestrial biomass (Kallmeyer et al., 2009). Living cells have been collected from a depth of nearly
$2000 \mathrm{~m}$ in submarine sediments (Ciobanu, 2012) and from nearly $4 \mathrm{~km}$ depth in South African gold mines (Onstott et al., 2006). It is interesting to note that, compared to most cells in surface environments, the average doubling time of subsurface microorganisms is very slow, of the order of 1 cell/1000 years (Jørgensen and D'Hondt, 2006)!

\subsection{Challenging conditions: life in survival mode}

Modern microbial life is remarkably resilient and capable of flourishing under extreme (for us) conditions, provided the necessary requirements are available (temperature, pressure, salinity, water activity, $\mathrm{pH}$, radiation, etc.; Rothschild and Mancinelli, 2001; Pikuta et al., 2007). For the purposes of this discussion, we distinguish thriving life from life in survival mode. When the necessary conditions for life are no longer available, many species are capable of slipping into a survival or dormant mode. Under such conditions microbial cells either metabolize very slowly as noted above (Jørgensen and D'Hondt, 2006) or they do not metabolize at all. All the cell functions are reduced, and the cell simply waits for more clement conditions to return. Estimations regarding the length of times cells can survive on Earth vary. There are some reports of viable cells in 5 million-year-old permafrost (Gilichinsky et al., 2007) (although there is a strong likelihood of rejuvenation during the different interglacial cycles over the last 5 million years, for instance) and in 40 million-year-old amber (Cano and Borucki, 1995). Permian-Triassic (300-200 Ma) microbes have also been detected in salt deposits (Vreeland et al., 2000), although they are not necessarily as old as the formation in which they are found (McGenity et al., 2000). Whatever the respective merits 
of these observations, survival of microorganisms on geologically long timescales must necessarily be influenced and limited by the background radioactivity in the crust (Kminek et al., 2003).

\subsection{Habitability: a working definition}

The habitability of any rocky planet or satellite can be simply summarized as its capacity to host the necessary ingredients and conditions for life to appear (Southam and Westall, 2007; Hoehler and Westall, 2010). These are liquid water, endogenic and/or exogenic prebiotic molecules for constructing the macromolecules necessary for cellular life, a viable energy transfer mechanism (chemical or photonic), and bioessential elements and nutrients.

\section{Example of Habitability on Mars}

\subsection{The possible appearance of life on Mars}

There are an increasing number of reports of liquid water at the surface of Mars in the past from the instruments in orbit and on the ground, although it is still uncertain how much water there was on the surface or what was the importance of underground water reservoirs. Valley networks have been observed for tens of years and have been mapped over large parts of Noachian and some parts of Hesperian Mars (e.g., Hynek et al., 2010). Numerous alluvial fans occur in craters (di Achille and Hynek, 2010). Furthermore, the presence of significant water is suggested by the detection of phyllosilicate minerals, which likely represent surface weathering profiles produced by aqueous alteration of the basaltic crust (Poulet et al., 2005; Bibring et al., 2006; Fairén et al., 2010; Gaudin et al., 2011; Carter et al., 2012; Le Deit et al., 2012; Loizeau et al., 2012a). The mineralogical associations being analyzed in situ at the John Klein site by Curiosity provide more detailed information about the characteristics of the water producing the alteration assemblages and indicate deposition of a smectite phase under neutral $\mathrm{pH}$ (Grotzinger et al., 2013). Detected evaporite minerals indicate at least ephemeral liquid water at the surface (Gendrin et al., 2005; Tosca and McLennan, 2006). Possible weathering sequences in various regions of Mars could indicate developed pedogenesis during the Noachian (Bishop et al., 2008, Gaudin et al., 2011; Le Deit et al., 2012; Loizeau et al., 2012a; Carter et al., 2013). But deep alteration in extended regions of Mars (Ehlmann et al., 2011a; Loizeau et al., 2012b; Carter et al., 2013) also shows that groundwater circulation has been an important process in the martian crust. The presence of liquid water on Mars' surface requires a denser atmosphere than exists at present $\left(6 \mathrm{mmb} \mathrm{CO}_{2}\right)$, but the exact quantity of $\mathrm{CO}_{2}$ in the Pre-Noachian/Noachian atmosphere is not known. Recent models have shown that, even with a dense $\mathrm{CO}_{2}$ atmosphere, early Mars could not have been "warm and wet" and was, in fact, cold (Forget et al., 2013). However, Wordsworth et al. (2013) suggested that transiently "warm" conditions related to impacts or volcanism could have produced conditions favoring the formation of the late Noachian valley networks, even though the mid-late Noachian global conditions were probably icy.

Ehlmann et al. (2011a, 2011b) proposed a hydrological regime in which early Mars was characterized by ephemeral surficial water, driven largely by subsurface hydrothermal circulation. However, simulations show that it would have been possible to maintain a water-table level close to the surface over large areas for hundreds of millions of years (Andrews-Hanna and Lewis, 2011). This surface water regime, fueled by impact and volcanic heating (Wordsworth et al., 2013), would have culminated at the end of the Late Noachian; and from the Hesperian-Amazonian onward, groundwater processes only would have dominated. The level of the groundwater table was probably modulated by Mars' orbital parameters, which would have influenced the volume of water ice in the polar caps and in the midlatitudes. Local warming of the environment by volcanism and impacts would have been sporadic, but there should have been many events of water flowing at the surface of Mars, as evidenced by the numerous dendritic valley networks incising Noachian and early Hesperian terrains. Lakes would have also been episodically filled when fed by the rising water table. For example, this is what is assumed to have happened in Meridiani Planum (Grotzinger et al., 2005; Squyres and Knoll, 2005; Andrews-Hanna et al., 2010) and could explain detections of clays and sulfates in Gale Crater from the ground on the crater floor and from orbit at the base of Mount Sharp (Milliken et al., 2010).

Both the mineralogical and the morphological evidence indicates a degradation in the surface conditions of Mars conducive to the proliferation of life from the mid Hesperian onward (Bibring et al., 2006; Carr and Head, 2009). The exact causes are not well understood but may be related to a combination of processes including loss of early atmosphere, whether from solar wind erosion (Jakosky and Phillips, 2001) or impact erosion (Brain and Jakosky, 1998) or both. The loss of the atmosphere was accompanied by decreasing temperatures. A part of the liquid water inventory sublimed and was transported to the poles, while the rest became trapped in a subsurface cryosphere (Clifford, 1993; Clifford and Parker, 2001). Thereafter, any low-lying areas that may have been episodically inundated, for example, by catastrophic outflows, would have lost their water very rapidly through sublimation, evaporation in the tenuous atmosphere, and infiltration in the crust. Crater lakes, however, if fed by an active hydrothermal system, may have lived longer, but this activity still requires the presence of underground water (liquid or ice). Observations on Earth (Osinski et al., 2005) and numerical modeling (e.g., Abramov and Kring, 2005; Schwenzer and Kring, 2009) have shown that a crater-forming impact can result in the creation of a longlasting hydrothermal system when ice is present in the crust. For example, a $130 \mathrm{~km}$ large crater could sustain an active hydrothermal system for up to 2 million years (Schwenzer and Kring, 2009), that is, long enough for life to emerge. Finally, even in the relatively recent past, there is some geomorphological evidence for extremely short-lived aqueous activity (Fenton et al., 2007; Mangold et al., 2007). It is interesting to note that whatever the fate of conditions on the surface of Mars through time, Jakosky and Shock (1998) estimated that there would not be sufficient geochemical energy to sustain abundant, flourishing life for more than 100 million years.

For the largest portion of martian history, the presence of surface water was patchy and infrequent. As a consequence, conditions favorable for the origin of life, compared to Earth, would have been heterogeneous in space and time. Cockell 
et al. (2012) also pointed out the lack of connectivity between potential habitats on Mars. Even if the right ingredients and conditions would have been available long enough for the origin of life and the development of primitive organisms, early life on Mars would have been more heterogeneous than that of Earth, where the global ocean provides for rapid transport and mixing. A certain amount of mixing between habitable environments on Mars could be envisaged if supported by an efficient subsurface hydrological regime, but generally the surface habitats were probably simply isolated environments. There are some differences between Earth and Mars in the environments in which life could have appeared. On Earth, hydrothermal environments and intertidal areas are the favored hypotheses. Hydrothermal environments associated with volcanism and impact craters would have been abundant on early Mars. The swash zone, related to tidal pull, would be inexistent. On the other hand, the fact that the planet was basically dry means that the scenario envisaged by Benner et al. (2010) for life arising in a stream on exposed serpentinized crust could be more likely than on Earth.

\subsection{Conditions for established life on Mars}

As on early Earth, the volcanic and hydrothermal environment on early Mars would have supported chemoautotrophic life-forms ( $c f$. Sleep and Bird, 2007). In this respect, the recent detection of serpentine in some outcrops associated with impact ejection of rocks from hundreds of meters' or kilometers' depth (the serpentine could also be due locally to postcrater hydrothermal activity) and with an olivine deposit near Nili Fossae (Ehlmann et al., 2010; Bultel et al., 2013) is of interest. Serpentinization produces $\mathrm{H}_{2}$ that serves as a source of energy (electron donor) for chemosynthetic life-forms (Schulte et al., 2006). Other sources of energy could have included $\mathrm{H}_{2}, \mathrm{O}_{2}, \mathrm{NO}_{3}{ }^{-}, \mathrm{SO}_{4}{ }^{2-}$, or organic sources, such as the degraded remains of dead organisms, acetate, or abiotic/prebiotic organics, for heterotrophs (Southam and Westall, 2007; Des Marais et al., 2008; Hoehler and Westall, 2010; Summons et al., 2011). Sunlight was and is still a potential source of energy on Mars, but martian microbes, if present, may not have had the necessary conditions for developing phototrophy. On Earth, photosynthesis appeared on a continuously habitable planet that had more or less uninterrupted access to energy, carbon, and nutrients, although the possibility of sterilization of the surface of Earth (but not the subsurface) by massive impacts during the Late Heavy Bombardment $(\sim 3.9 \mathrm{Ga})$ has been proposed by Zahnle and Sleep (2006) (and refuted by Abramov and Mojzsis, 2009). The continued habitability of at least some parts of the upper crust meant that terrestrial life-forms would not have undergone the stop-and-start scenarios that may well have characterized the fate of any early martian life. Photosynthesis developed in terrestrial microorganisms that had direct access to sunlight, that is, in shallow coastal areas (littoral). It was present on Earth at least 3.5 billion years ago (Tice and Lowe, 2004; Allwood et al., 2006; Westall et al., 2006a) and possibly by 3.8 billion years ago (Mojzsis et al., 1996; Rosing, 1999; Rosing and Frei, 2004). These kinds of shallow water environments were probably common at various times on early Mars, but were they suitable for the evolution of photosynthetic microorgan- isms? Apart from the question of the time necessary for continuous evolution to result in photosynthesis, another factor that may have been important is the distance between Mars and the Sun. Mars is farther away from the Sun, whose luminosity was fainter in the early phases of its history (Sagan and Chyba, 1997); that is, Mars was likely outside the Sun's habitable zone. What impact did this have on standing bodies of water on Mars? Despite the geomorphological and mineralogical evidence for water at the surface of the planet, particularly during its early history, attempts at modeling the evolution of the atmosphere suggest that Mars was always very cold and that liquid water would not have been present on its surface for long (Forget et al., 2013; Wordsworth et al., 2013). The implication is that, where present, the bodies of water may have been ice-covered, thus hindering the development of photosynthesis. Martian life, if it existed, may have remained at a very primitive state of evolution.

The rock record does not record the appearance of life on Earth, but it seems that the ingredients were available already by $\sim 4.4 \mathrm{Ga}$ given that there is evidence of lowtemperature hydrothermal alteration of the crust (Cavosie et al., 2005). The first living cells would have had only a minimal number of metabolic and reproductive components. They were probably very small, similar to micelles ( $c f$. Luisi et al., 2006), and possibly comparable in size to viruses. Even by $3.45 \mathrm{Ga}$, a time from which we have the first morphologically preserved microorganisms (chemotrophic), the cells are still very small, $<1 \mu \mathrm{m}$ in size (Westall et al., 2006b, 2011) (similar to the sizes of modern subsurface chemotrophic microorganisms, $\sim 0.2 \mu \mathrm{m}$; Ciobanu, 2012). Primitive martian microorganisms, if in existence at the time, might have had (and may still have) similar characteristics, remaining very small. The amount of biomass that can be produced by chemosynthesis is much lower than that produced by photosynthesis. Sleep and Bird (2007) calculated that less than $0.056 \mathrm{Tmol} \mathrm{y}^{-1}$ of organic carbon (biomass) would have been buried in sediments on Earth in the period prior to the appearance of photosynthesis, compared with $10 \mathrm{Tmol}^{-1}$ today! They thus concluded that the record of chemosynthetic life must be "sparse and dispersed."

If life was established on Mars, it could have colonized even ephemeral habitats, especially if the habitats were interconnected (cf. Cockell et al., 2012). Microbial life could have been hosted in short-lived habitats, such as small impact craters, playa lakes, and so on, or transiently protected habitats, such as under the surfaces of ice sheets, rocks, or in cracks where water could be trapped ( $c f$. terrestrial endoliths; Friedmann and Koriem, 1989). These habitats may have involved much smaller spatial and temporal scales than those necessary for supporting the emergence of life. As soon as the habitable conditions disappeared-for example due to loss of water through freezing/sublimation or exhaustion of carbon source, nutrients, or energy-any putative martian organisms would have first gone into survival mode, eventually dying, unless the conditions changed and the missing ingredients were replenished. Opportunistic colonization of a habitat could have occurred at any time in martian history, if life were able to remain in a viable state and be transported to the newly available habitat. But, as noted by Cockell et al. (2012), a habitable environment may remain uninhabited, if no viable forms of life can be transported to it. 
Table 1. Spatial and Temporal Scales of the Different Categories for Microbial Habitability

\begin{tabular}{ll}
\hline Habitability scales & Time \\
\hline
\end{tabular}

Origin of life

$10^{5}$ to $10^{6} \mathrm{y}$ ?

$10^{1}$ to $10^{3} \mathrm{~km}$
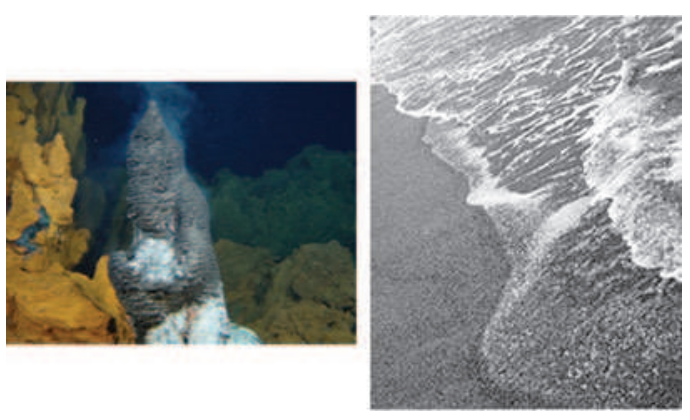

$10^{2}$ to $10^{3} \mu \mathrm{m}$
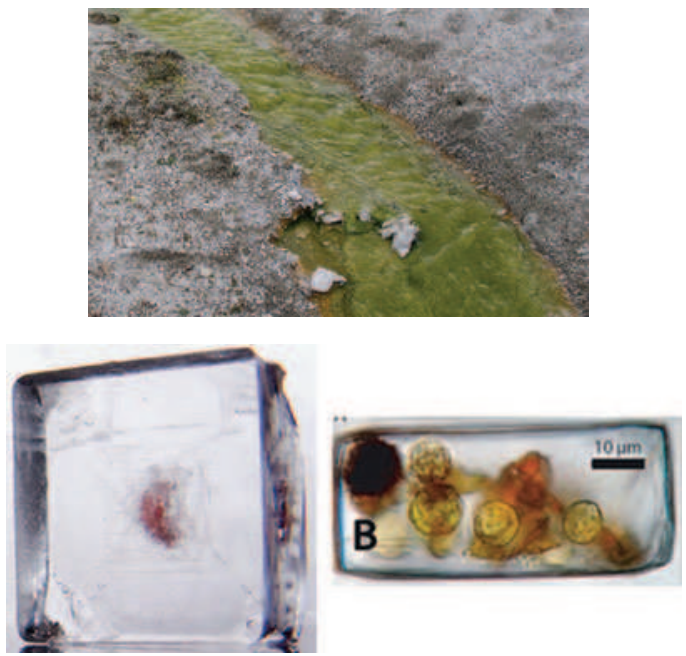

Images: Top left, black smoker; top right, swash zone. Middle, outflow stream from a hydrothermal spring in Yellowstone. The barren sinter is colonized by photosynthetic microbial mats growing in the habitable outflow channel. Bottom left, salt crystal with entombed halophilic microbes. Bottom right, halophiles in a fluid inclusion in a salt crystal. (Image credits: Top left, Ifremer; Top right, F. Westall; Middle, F. Westall; Bottom left and right, H. Stan-Lotter.)

The most likely refuge for life on Mars after the degradation of habitable conditions at the surface is the subsurface, where it may have spread via groundwater to even greater crustal depths than on Earth (microbes have been retrieved from depths in the order of $3 \mathrm{~km}$; Onstott et al., 2006), owing to the thicker martian crust and lower heat flux. Whether present in a viable form in subsurface liquid oases or in frozen form in the cryosphere, martian life could have been brought back to the surface at various times during the history of the planet, whenever subsurface aquifers or the liquefied cryosphere erupted to the surface, for example through hydrothermal systems linked to volcanism or impacts.
A

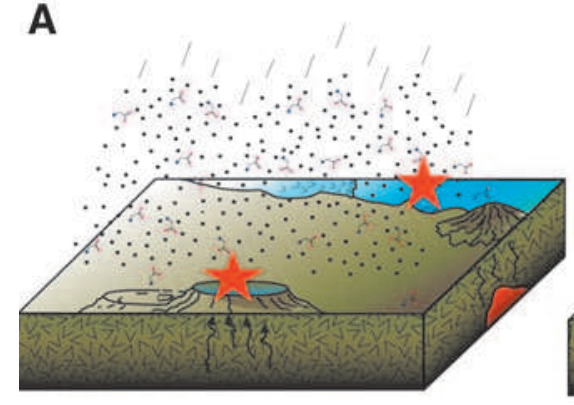

B

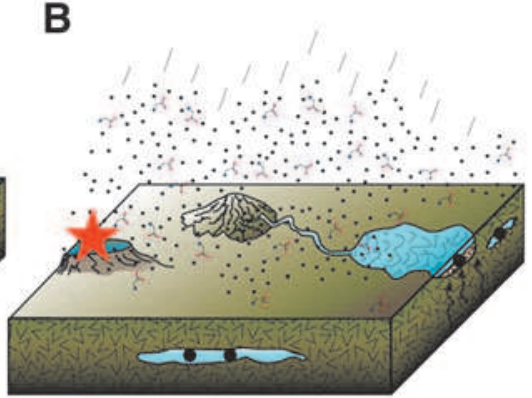

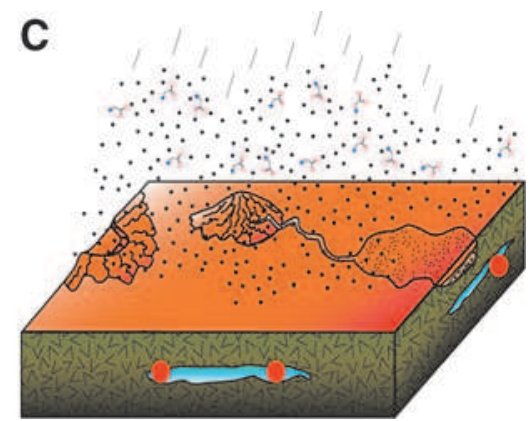

FIG. 3. Variable conditions favoring life on Mars. (A) Sketch representing early Mars with two types of unconnected habitable environments that could have supported the emergence of life (indicated by the red stars) - a lake in an impact crater and a larger water body. (B) Changing habitability on Mars. In one location a crater lake could host conditions conducive to the emergence of life, while simultaneously in another unconnected habitat extant life may be flourishing in the sediments at the bottom of an icecovered body of water (black dots). Extant life is also present in the subsurface. (C) No habitable conditions at the surface of Mars. The frozen cryosphere may still host dormant cells (red dots). In all scenarios there is a continuous rain of extraterrestrial organics. 


\subsection{Surviving on Mars}

If martian life did reach the subsurface, it is in this environment where we may have the best opportunity to discover it, especially considering the restrictive surface conditions after about 3.5 Ga (Jakosky et al., 2007; Sleep, 2010). However, microbes in a subsurface environment would need to be able to repair and renew their genetic machinery to counteract the background radiation effects over time. Without such ongoing or regular repairs, the survival of dormant life-forms is limited to several 100,000 years close to the surface (but protected from direct UV radiation) and to several hundred million years if protected from the ionizing radiation from space and only exposed to natural radioactivity (Kminek et al., 2003). It is worth pointing out that there are natural cycles on Mars; that is, obliquity changes, which may result in windows affording conditions for such repairs. To take advantage of such brief, clement episodes, martian microbes would need to be "ready and waiting" in the subsurface, that is, in a viable state. Upon being "revived," they would have to divide and metabolize before either dying out or seeping back into the upper crust with the water flow, once again becoming cryofrozen.

Table 1 summarizes the ranges of spatial and temporal scales for the origin of life and for established or surviving life scenarios, while Fig. 3 summarizes the different categories of habitability on Mars, which could have coexisted. The existence of isolated habitable environments means that, at any one time during the early history of the planet, life could have emerged in one location while it was well established in another or dormant in a third. The sketches also have a sequential implication related to the changing (degrading) conditions of surface habitability with time. The prime environment of recharge was probably the subsurface, with an alternating water table/cryosphere activated by heat of geothermal, hydrothermal, volcanic, or impact origin. Precipitation and water ice deposition would have been additional sources of water.

\section{Conclusions}

In principle, life should be able to emerge on any rocky planet having water in contact with rocks and an abundant supply of prebiotic molecules, hence constituting a universal phenomenon. However, a closer look at the conditions supporting prebiotic chemistry, the origin and evolution of life, and its survival shows just how delicate this conclusion can be. On Mars, there is plenty of evidence indicating water in contact with rocks. Additionally, early Mars had the same inventory of exogenous prebiotic molecules as young Earth-although today a number of surface physical and chemical agents are likely responsible for degrading at least the more volatile organic components. Nevertheless, there is a major difference in the habitable conditions of the two planets in terms of spatial and temporal scales. For life to emerge, favorable conditions and ingredients need to be present for up to a couple of million years. For established life, the temporal and spatial scales are less restrictive. Conditions allowing active metabolism and replication come about every few hundred or thousand years on scales as reduced as some tens of microns to perhaps decimeters. Following a relatively short period during which life may have gained a foothold on the Red Planet, when conditions may have been similar to those on young Earth, the number of potentially habitable environments for established life throughout Mars' history was probably very large. Suitable conditions may still exist in the subsurface, but they may not necessarily have been inhabited.

This heterogeneity in the distribution of environments supporting the origin, evolution, and survival of life over Mars' history will have a significant impact on the planning of missions seeking to find traces of life, in particular because locations supporting one habitable element, for example the initial conditions giving rise to life, might not support another element, such as ephemeral habitats that might support life for very brief periods of time (Westall et al., in preparation).

\section{References}

Abramov, O. and Kring, D.A. (2005) Impact-induced hydrothermal activity on early Mars. J Geophys Res 110, doi:10.1029/ 2005JE002453.

Abramov, O. and Mojzsis, S.J. (2009) Microbial habitability of the Hadean Earth during the Late Heavy Bombardment. Nature 459:419-422.

Allwood, A.C., Walter, M.R., Kamber, B.S., Marshall, C., and Burch, I.W. (2006) Stromatolite reef from the Early Archaean era of Australia. Nature 441:714-718.

Alpermann, T.J., Tillmann, U., Beszteri, B., Cembella, A.D., and John, U. (2010) Phenotypic variation and genotypic diversity in a planktonic population of the toxigenic marine dinoflagellate Alexandrium tamarense (Dinophyceae). J Phycol 46: 18-32.

Andrews-Hanna, J.C. and Lewis, K.W. (2011) Early Mars hydrology: 2. Hydrological evolution in the Noachian and Hesperian epochs. J Geophys Res 116, doi:10.1029/ 2010JE003709.

Andrews-Hanna, J.C., Zuber, M.T., Arvidson, R.E., and Wiseman, S.M. (2010) Early Mars hydrology: Meridiani playa deposits and the sedimentary record of Arabia Terra. J Geophys Res 115, doi:10.1029/2009JE003485.

Bada, J.L. (2004) How life began on Earth: a status report. Earth Planet Sci Lett 226:1-15.

Bada, J.L., Bigham, C., and Miller, S.L. (1994) Impact melting of frozen oceans on the early Earth: implications for the origin of life. Proc Natl Acad Sci USA 91:1248-1250.

Baross, J.A. and Hoffman, S.E. (1985) Submarine hydrothermal vents and associated gradient environments as sites for the origin and evolution of life. Orig Life Evol Biosph 15:327-345.

Benner, S.A, Kim, H.-Y., Kim M.-J., and Ricardo, A. (2010) Planetary organic chemistry and the origins of biomolecules. Cold Spring Harb Perspect Biol 2, doi:10.1101/cshperspect.a003467.

Bernstein, M.P., Sandford, S.A., and Allamandola, L.J. (1999) Life's far-flung raw materials. Sci Am 281:42-49.

Bibring, J.P., Langevin, Y., Mustard, J.F., Poulet, F., Arvidson, R., Gendrin, A., Gondet, B., Mangold, N., Pinet, P., Forget, F., Berthé, M., Bibring, J.P., Gendrin, A., Gomez, C., Gondet, B., Jouglet, D., Poulet, F., Soufflot, A., Vincendon, M., Combes, M., Drossart, P., Encrenaz, T., Fouchet, T., Merchiorri, R., Belluci, G., Altieri, F., Formisano, V., Capaccioni, F., Cerroni, P., Coradini, A., Fonti, S., Korablev, O., Kottsov, V., Ignatiev, N., Moroz, V., Titov, D., Zasova, L., Loiseau, D., Mangold, N., Pinet, P., Douté, S., Schmitt, B., Sotin, C., Hauber, E., Hoffmann, H., Jaumann, R., Keller, U., Arvidson, R., Mustard, J.F., Duxbury, T., Forget, F., and Neukum, G. (2006) Global min- 
eralogical and aqueous Mars history derived from OMEGA/ Mars Express data. Science 312:400-404.

Bishop, J.L., Noe Dobrea, E.Z., McKeown, N.K., Parente, M., Ehlmann, B.L., Michalski, J.R., Milliken, R.E., Poulet, F., Swayze, J.A., Mustard, J.F., Murchie, S.L., and Bibring, J.P. (2008) Phyllosilicate diversity and past aqueous activity revealed at Mawrth Vallis, Mars. Science 321:830-833.

Bougault, H., Charlou, J.-L., Fouquet, Y., Needham, H.D., Vaslet, N., Appriou, P., Baptiste, P.J., Rona, P.A., Dmitriev, L., and Silantiev, S. (1993) Fast and slow spreading ridges: structure and hydrothermal activity, ultramafic topographic highs, and $\mathrm{CH}_{4}$ output. J Geophys Res 98:9643-9651.

Brack, A. (1999) Life in the Solar System. In Life Sciences: New Insights into Complex Organics in Space, edited by P. Ehrenfreund and F. Robert, Advances in Space Research 24:417-433.

Brain, D.A. and Jakosky, B.M. (1998) Atmospheric loss since the onset of the martian geological record: combined role of impact erosion and sputtering. J Geophys Res 103:22689-22694.

Buffett, B.A. (2003) The thermal state of Earth's core. Science 299:1675-1676.

Bultel, B., Quantin, C., Andreani, M., and Clenet, H. (2013) Identification of phyllosilicates in crustal outcrops between Hellas and Isidis Basins (Mars) using combinaison of near 2.3$2.5 \mu \mathrm{m}$ absorptions on CRISM data [abstract 2078]. In 44 ${ }^{\text {th }}$ Lunar and Planetary Science Conference, Lunar and Planetary Institute, Houston.

Cano, R. and Borucki, M.K. (1995) Revival and identification of bacterial spores in 25-to 40-million-year-old Dominican amber. Science 268:1060-1064.

Carr, M.H. and Head, J.W. (2009) Geologic history of Mars. Earth Planet Sci Lett 294:185-203.

Carter, J., Poulet, F., Bibring, J.-P., and Murchie, S.M. (2012) Composition, setting and timing of clays on Mars: an evolutionary pathway [abstract 7050]. In Third Conference on Early Mars: Geologic, Hydrologic, and Climatic Evolution and the Implications for Life, Lunar and Planetary Institute, Houston.

Carter, J., Loizeau, D., Mangold, N., Poulet, F., and Bibring, J.-P. (2013) Widespread surface weathering on early Mars: a case for a warmer and wetter Mars [abstract 1755]. In $44^{\text {th }}$ Lunar and Planetary Science Conference, Lunar and Planetary Institute, Houston.

Cavosie, A.J., Valley, J.W., Wilde, S.A, and E.I.M.F. (2005) Magmatic $\delta^{18} \mathrm{O}$ in 4400-3900 Ma detrital zircons: a record of the alteration and recycling of crust in the Early Archean. Earth Planet Sci Lett 235:663-681.

Chyba, C.F. and Sagan, C. (1992) Endogenous production, exogenous delivery and impact-shock synthesis of organic molecules: an inventory for the origins of life. Nature 355:125-132.

Chyba, C.F., Thomas, P.J., Brookshaw, L., and Sagan, C. (1990) Cometary delivery of organic molecules to the early Earth. Science 249:366-373.

Ciobanu, M.-C. (2012) Biosphère de subsurface de marges continentals: diversité, étendue et lien avec le paléoenvironment. PhD thesis, Université de Bretagne Occidentale, Brest, France.

Clifford, S.M. (1993) A model for the hydrologic and climatic behavior of water on Mars. J Geophys Res 98, doi:10.1029/ 93JE00225.

Clifford, S.M. and Parker, T.J. (2001) The evolution of the martian hydrosphere: implications for the fate of a primordial ocean and the current state of the northern plains. Icarus 154:40-79.

Cockell, C.S., Balme, M., Bridges, J.C., Davilad, A., and Schwenzer, S.P. (2012) Uninhabited habitats on Mars. Icarus 217:184-193. de Marcellus, P., Bertrand, M., Nuevo, M., Westall, F., and D'Hendecourt, L. (2011) Prebiotic significance of extraterrestrial ice photochemistry: detection of hydantoin in organic residues. Astrobiology 11:847-854.

Deamer, D., Dworkin, J.P., Sandford, S.A., Bernstein, M.P., and Allamandola, L.J. (2002) The first cell membranes. Astrobiology 2:371-381.

Des Marais, D.J., Jakosky, B.M., and Hynek, B.M. (2008) Astrobiological implications of Mars' surface composition and properties. In The Martian Surface, edited by J. Bell, Cambridge University Press, Cambridge, UK, pp 599-624.

di Achille, G. and Hynek, B.M. (2010) Ancient ocean on Mars supported by global distribution of deltas and valleys. Nat Geosci 3:459-463.

Ehlmann, B.L., Mustard, J.F., and Murchie, S.L. (2010) Geologic setting of serpentine deposits on Mars. Geophys Res Lett 37, doi:10.1029/2010GL042596.

Ehlmann, B.L., Mustard, J.F., Clark, R.N., Swayze, G.A., and Murchie, S.L. (2011a) Evidence for low-grade metamorphism, hydrothermal alteration, and diagnosis on Mars from phyllosilicate mineral assemblages. Clays Clay Miner 59:359-377.

Ehlmann, B.L., Mustard, J.F., Murchie, S.L., Bibring, J.-P., Meunier, A., Fraeman, A.A., and Langevin, Y. (2011b) Subsurface water and clay mineral formation during the early history of Mars. Nature 479:53-60.

Fairén, A.G., Chevrier, V., Abramov, O., Marzoe, G.A., Gavin, P., Davila, A.F., Tornabene, L.L., Bishop, J.A., Roush, T.L., Gross, C., Kneissl, T., Uceda, E.R., Dohm, J.M., Schulze-Makuch, D., Rodríguez, J.A.P., Amils, R., and McKay, C.P. (2010) Noachian and more recent phyllosilicates in impact craters on Mars. Proc Natl Acad Sci USA 107:12095-12100.

Fenton, L.K., Geissler, P.E., and Haberle, R.M. (2007) Global warming and climate forcing by recent albedo changes on Mars. Nature 446:646-649.

Forget, F., Wordsworth, R., Millour, E., Madeleine, J.-B., Kerber, L., Leconte, J., Marcq, E., and Haberle, R.M. (2013) Global modeling of the early martian climate under a denser $\mathrm{CO}_{2}$ atmosphere: temperature and $\mathrm{CO}_{2}$ ice clouds. Icarus 222:8-99.

Friedmann, E.I. and Koriem, A.M. (1989) Life on Mars: how it disappeared (if it was ever there). Adv Space Res 9:167-172.

Gaucher, E.A., Kratzer, J.T., and Randall, R.N. (2010) Deep phylogeny: how a tree can help characterize early life on Earth. Cold Spring Harb Perspect Biol 2, doi:10.1101/cshperspect.a002238.

Gaudin, A., Dehouck, E., and Mangold, N. (2011) Evidence for weathering on early Mars from a comparison with terrestrial weathering profiles. Icarus 216:257-268.

Gendrin, A., Mangold, N., Bibring, J.P., Langevin, Y., Gondet, B., Poulet, F., Bonello, G., Quantin, C., Mustard, J., Arvidson, R., and LeMouélic, S. (2005) Sulfates in martian layered terrains: the OMEGA/Mars Express view. Science 307:1587-1591.

Gilichinsky, D.A., Wilson, G.S., Friedmann, E.I., McKay, C.P., Sletten, R.S., Rivkina, E.M., Vishnivetskaya, T.A., Erokhina, L.G., Ivanushkina, N.E., Kochkina, G.A., Shcherbakova, V.A., Soina, V.S., Spirina, E.V., Vorobyova, E.A., Fyodorov-Davydov, D.G., Hallet, B., Ozerskaya, S.M., Sorokovikov, V.A., Laurinavichyus, K.S., Shatilovich, A.V., Chanton, P., Ostroumov, V.E., and Tiedje, J.M. (2007) Microbial populations in Antarctic permafrost: biodiversity, state, age and implication for astrobiology. Astrobiology 7:275-311.

Grotzinger, J.P. and Kasting, J.F. (1993) New constraints on Precambrian ocean composition. J Geol 101:235-243.

Grotzinger, J.P., Arvidson, R.E., Bell, J.F., III, Calvin, W., Clark, B.C., Fike, D.A., Golombek, M., Greeley, R., Haldemann, A., 
Herkenhoff, K.E., Jolliff, B.L., Knoll, A.H., Malin, M., McLennan, S.M., Parker, T., Soderblom, L., Sohl-Dickstein, J.N., Squyres, S.W., Tosca, N.J., and Watters, W.A. (2005) Stratigraphy and sedimentology of a dry to wet eolian depositional system, Burns Formation, Meridiani Planum, Mars. Earth Planet Sci Lett 240:11-72.

Grotzinger, J.P., Blake, D.F., Crisp, J., Edgett, K.S., Gellert, R., Gómez-Elvira, J., Hassler, D., Mahaffy, P., Malin, M.C., Mitrofanov, I.G., Meyer, M., Vasavada, A.R., Wiens, R.C., and the MSL Science Team. (2013) Mars Science Laboratory: first 100 sols of geologic and geochemical exploration from Bradbury Landing to Glenelg [abstract 1259]. In $44^{\text {th }}$ Lunar and Planetary Science Conference, Lunar and Planetary Institute, Houston.

Hazen, R.M. and Sverjensky, D.A. (2010) Mineral surfaces, geochemical complexities, and the origins of life. Cold Spring Harb Perspect Biol 2, doi:10.1101/cshperspect.a002162.

Herbst, E. and van Dishoeck, E.F. (2009) Complex organic interstellar molecules. Annu Rev Astron Astrophys 47:427-480.

Hoehler, T. and Westall, F. (2010) Mars Exploration Program Analysis Group Goal One: determine if life ever arose on Mars. Astrobiology 10:859-867.

Hofmann, A. and Bolhar, R. (2007) Carbonaceous cherts in the Barberton greenstone belt and their significance for the study of early life in the Archean record. Astrobiology 7: 355-388.

Huber, C. and Wächtershäuser, G. (1998) Peptides by activation of amino acids with $\mathrm{CO}$ on $(\mathrm{Ni}, \mathrm{Fe}) \mathrm{S}$ surfaces: implications for the origin of life. Science 281:670-672.

Hynek, B.M., Beach, M., and Hoke, M.R.T. (2010) Updated global map of martian valley networks and implications for climate and hydrologic processes. J Geophys Res 115, doi:10.1029/2009JE003548.

Jakosky, B.M. and Phillips, R.J. (2001) Mars' volatile and climate history. Nature 412:237-244.

Jakosky, B.M. and Shock, E.L. (1998) The biological potential of Mars, the early Earth, and Europa. J Geophys Res 103:19359-19364.

Jakosky, B., Westall, F., and Brack, A. (2007) Mars. In Planets and Life: The Emerging Science of Astrobiology, edited by W. Sullivan and J. Baross, Cambridge University Press, Cambridge, pp 357-387.

Johnson, A.P., Cleaves, H.J., Dworkin, J.P., Glavin, D.P., Lazcano, A., and Bada, J.L. (2008) The Miller volcanic spark discharge experiment. Science 322:404.

Jørgensen, B. and D'Hondt, S. (2006) A starving majority deep beneath the seafloor. Science 314:932-934.

Kallmeyer, J., Pockalny, R., and D'Hondt, S. (2009) Quantifying global subseafloor abundance: method and implications. Geochim Cosmochim Acta 73:A615.

Kminek, G., Bada, J.L., Pogliano, K., and Ward, J.F. (2003) Radiation-dependent limit for the viability of bacterial spores in halite fluid inclusions and on Mars. Radiat Res 159:722-729.

Larralde, R., Robertson, M., and Miller, S. (1995) Rates of decomposition of ribose and other sugars: implications for chemical evolution. Proc Natl Acad Sci USA 92:8158-8160.

Le Deit, L., Flahaut, J., Quantin, C., Hauber, E., Mège, D., Bourgeois, O., Gurgurewicz, J., Massé, M., and Jaumann, R. (2012) Extensive surface pedogenic alteration of the martian Noachian crust suggested by plateau phyllosilicates around Valles Marineris. J Geophys Res 117, doi:10.1029/2011JE003983.

Loizeau, D., Werne, S.C., Mangold, N., Bibring, J.-P., and Vago, J.L. (2012a) Chronology of deposition and alteration in the Mawrth Vallis region, Mars. Planet Space Sci 72:31-43.

Loizeau, D., Carter, J., Bouley, S., Mangold, N., Poulet, F., Bibring, J.-P., Costard, F., Langevin, Y., Gondet, B., and
Murchie, S.L. (2012b) Characterization of hydrated silicatebearing outcrops in Tyrrhena Terra, Mars. Icarus 219:476-497.

Luisi, P.L., Ferri, F., and Stano, P. (2006) Approaches to semisynthetic minimal cells: a review. Naturwissenschaften 93:1-13.

Mangold, N., Poulet, F., Mustard, J., Bibring, J.-P., Gondet, B., Langevin, Y., Ansan, V., Masson, Ph., Fassett, C., Head, J., Hoffmann, H., and Neukum, G. (2007) Mineralogy of the Nili Fossae region with OMEGA/Mars Express data: 2. Aqueous alteration of the crust. J Geophys Res 112, doi:10.1029/ 2006JE002835.

Mansy, S.S. and Szostak, J.W. (2008) Thermostability of model protocell membranes. Proc Natl Acad Sci USA 105:1335113355.

Maurette, M. (1998) Carbonaceous micrometeorites and the origin of life. Orig Life Evol Biosph 28:385-412.

Maurette, M., Matrajit, G., Gounelle, M., Engrand, C., and Duprat, J. (2001) La matière extraterrestre primitive et les mystères de nos origines. In L'Environnement de la Terre Primitive, edited by M. Gargaud, D. Despois, and J.-P. Parisot, Presses Universitaires de Bordeaux, Bordeaux, pp 99-127.

McGenity, T.J., Gemmell, R.T., Grant, W.D., and Stan-Lotter, H. (2000) Origins of halophilic microorganisms in ancient salt deposits. Environ Microbiol 2:243-250.

Miller, S.L. (1953) A production of amino acids under possible primitive Earth conditions. Science 117:528-529.

Milliken, R.E., Grotzinger, J.P., and Thomson B.J. (2010) Paleoclimate of Mars as captured by the stratigraphic record in Gale Crater. Geophys Res Lett 37, doi:10.1029/ 2009GL041870.

Mojzsis, S.J., Arrhenius, G., Keegan, K.D., Harrison, T.H., Nutman, A.P., and Friend, C.L.R. (1996) Evidence for life on Earth before 3,800 million years ago. Nature 384:55-59.

Onstott, T.C., Lin, L.-H., Davidson, M., Mislowack, B., Borcsik, M., Hall, J., Slater, G., Ward, J., Sherwood Lollar, B., Lippmann-Pipke, J., Boice, E., Pratt, L.M., Pfiffner, S.M., Moser, D.P., Gihring, T.M., Kieft, T., Phelps, T.J., van Heerden, E., Litthaur, D., DeFlaun, M., Rothmel, R., Wanger, G., and Southam, G. (2006) The origin and age of biogeochemical trends in deep fracture water of the Witwatersrand Basin, South Africa. Geomicrobiol J 23:369-414.

Orgel, L.E. (1998) Prebiotic chemistry and the origin of the RNA world. Crit Rev Biochem Mol Biol 39:99-123.

Oró, J. (1961) Comets and the formation of biochemical compounds on the primitive Earth. Nature 190:389-390.

Osinski, G.R., Pascal, L., Parnell, J., Spray, J.G., and Baron, M. (2005) A case study of impact-induced hydrothermal activity: the Haughton impact structure, Devon Island, Canadian High Arctic. Meteorit Planet Sci 40:1859-1877.

Ourisson, G. and Nakatani, Y. (1999) Origins of cellular life: molecular foundations and new approaches. Tetrahedron 55:3183-3190.

Pascal, R. (2013) Life, metabolism and energy. In Astrochemistry and Astrobiology, edited by I. Smith, C.S. Cockell, and S. Leach, Springer, Berlin, pp 243-270.

Pascal, R., Boiteau, L., Forterre, P., Gargaud, M., Lazcano, A., Lopez-Garcia, P., Maurel, M.-C., Moreira, D., Pereto, J., Prieur, D., and Reisse, J. (2006) Prebiotic chemistry-biochemistryemergence of life (4.4-2 Ga). Earth Moon Planets 98:153-203.

Pikuta, E.V., Hoover, R.B., and Tang, J. (2007) Microbial extremophiles at the limits of life. Crit Rev Microbiol 33: 183-209.

Pollack, G.H., Figueroa, X., and Zhao, Q. (2009) Molecules, water, and radiant energy: new clues for the origin of life. Int $J$ Mol Sci 10:1419-1429. 
Poulet, F., Bibring, J.P., Mustard, J.F., Gendrin, A., Mangold, N., Langevin, Y., Arvidson, R.E., Gondet, B., Gomez, C., Berthé, M., Erard, S., Forni, O., Manaud, N., Poulleau, G., Soufflot, A., Combes, M., Drossart, P., Encrenaz, T., Fouchet, T., Melchiorri, R., Bellucci, G., Altieri, F., Formisano, V., Fonti, S., Capaccioni, F., Cerroni, P., Coradini, A., Korablev, O., Kottsov, V., Ignatiev, N., Titov, D., Zasova, L., Pinet, P., Schmitt, B., Sotin, C., Hauber, E., Hoffmann, H., Jaumann, R., Keller, U., Forget, F., and the Omega Team. (2005) Phyllosilicates on Mars and implications for early martian climate. Nature 438:623-627.

Pross, A. and Pascal, R. (2013) The origin of life: what we know, what we can know and what we will never know. Open Biol 3, doi:10.1098/rsob.120190.

Rosing, M.T. (1999) ${ }^{13} \mathrm{C}$ depleted carbon microparticles in $>3700$ Ma seafloor sedimentary rocks from West Greenland. Science 283:674-676.

Rosing, M.T. and Frei, R. (2004) U-rich Archaean sea-floor sediments from Greenland-indications of >3700 Ma oxygenic photosynthesis. Earth Planet Sci Lett 217:237-244.

Rothschild, L.J. and Mancinelli, R.L. (2001) Life in extreme environments. Nature 409:1092-1101.

Russell, J.M., Hall., A.J., and Martin, W. (2010) Serpentinization and its contribution to the energy for the emergence of life. Geobiology 8:355-371.

Sagan, C. and Chyba, C. (1997) The early Sun paradox: organic shielding of ultraviolet-labile greenhouse gases. Science 276:1217-1221.

Schulte, M., Blake, D., Hoehler, T., and McCollom, T. (2006) Serpentinization and its implications for life on the early Earth and Mars. Astrobiology 6:364-376.

Schwenzer, S.P. and Kring, D.A. (2009) Impact-generated hydrothermal systems capable of forming phyllosilicates on Noachian Mars. Geology 37:1091-1094.

Sephton, M.A. and Botta, O. (2008) Extraterrestrial organic matter and the origin of life. Space Sci Rev 135:25-35.

Sievert, S.M. and Vetriani, C. (2012) Chemoautotrophy at deepsea vents: past, present, and future. Oceanography 25:218-233.

Sleep, N. (2010) The Hadean-Archaean environment. Cold Spring Harb Perspect Biol 2:a002527.

Sleep, N.H. and Bird, D.K. (2007) Niches of the pre-photosynthetic biosphere and geologic preservation of Earth's earliest ecology. Geobiology 5:101-117.

Southam, G. and Westall, F. (2007) Geology, life and habitability. In Treatise on Geophysics-Vol. 10 Planets and Moons, edited by T. Spohn, Elsevier, Amsterdam, pp 421-438.

Squyres, S.W. and Knoll, A.H. (2005) Sedimentary rocks at Meridiani Planum: origin, diagenesis, and implications for life on Mars. Earth Planet Sci Lett 240:1-10.

Summons, R.E., Amend, J.P., Bish, D., Buick, R., Cody, G.D., Des Marais, D.J., Dromart, G., Eigenbrode, J.L., Knoll, A.H., and Sumner, D.Y. (2011) Preservation of martian organic and environmental records: final report of the Mars Biosignature Working Group. Astrobiology 11:157-181.
Tice, M. and Lowe, D.R. (2004) Photosynthetic microbial mats in the 3,416-Myr-old ocean. Nature 431:549-552.

Tosca, N.J. and McLennan, S.M. (2006) Chemical divides and evaporite assemblages on Mars. Earth Planet Sci Lett 24:21-31. van den Boorn, S., Van Bergen, M.J., Nijman, W., and Vroon, P.Z. (2007) Dual role of seawater and hydrothermal fluids in Early Archean chert formation: evidence from silicon isotopes. Geology 35:939-942.

Vreeland, R.H., Rosenzweig, W.D., and Powers, D.W. (2000) Isolation of a 250 million-year-old halotolerant bacterium from a primary salt crystal. Nature 407:897-900.

Westall, F. and Southam, G. (2006) Early life on Earth. In Archean Geodynamics and Environments, edited by K. Benn, J.-C. Mareschal, and K.C. Condie, AGU Geophysical Monograph 164, American Geophysical Union, Washington, DC, pp 283-304.

Westall, F., de Ronde, C.E.J., Southam, G., Grassineau, N., Colas, M., Cockell, C., and Lammer, H. (2006a) Implications of a 3.472-3.333 Ga-old subaerial microbial mat from the Barberton greenstone belt, South Africa for the UV environmental conditions on the early Earth. Philos Trans $R$ Soc Lond B Biol Sci 361:1857-1875.

Westall, F., de Vries, S.T., Nijman, W., Rouchon, V., Orberger, B., Pearson, V., Watson, J., Verchovsky, A., Wright, I., Rouzaud, J.-N., Marchesini, D., and Anne, S. (2006b) The 3.466 Ga Kitty's Gap Chert, an Early Archaean microbial ecosystem. In Processes on the Early Earth, GSA Special Paper 405, edited by W.U. Reimold and R. Gibson, Boulder, CO, pp 105-131.

Westall, F., Foucher, F., Cavalazzi, B., de Vries, S.T., Nijman, W., Pearson, V., Watson, J., Verchovsky, A., Wright, I., Rouzaud, J.N., Marchesini, D., and Anne, S. (2011) Early life on Earth and Mars: a case study from $\sim 3.5$ Ga-old rocks from the Pilbara, Australia. Planet Space Sci 59:1093-1106.

Wordsworth, R., Forget, F., Millour, E., Head, J.W., Madeleine, J.-B., and Charnay, B. (2013) Global modelling of the early martian climate under a denser $\mathrm{CO}_{2}$ atmosphere: water cycle and ice evolution. Icarus 222:1-19.

Zahnle, K.J. and Sleep, N.H. (2006) Impacts and the early evolution of life. In Comets and the Origin and Evolution of Life, $2^{\text {nd }}$ ed., edited by P.J. Thomas, R.D. Hicks, C.F. Chyba, and C.P. McKay, Springer, New York, pp 207-251.

Address correspondence to: Frances Westall CNRS-OSUC-Centre de Biophysique Moléculaire Rue Charles Sadron 45071 Orléans cedex 2 France

E-mail: frances.westall@cnrs-orleans.fr

Submitted 12 March 2013 Accepted 9 June 2013 